\title{
Spatially Resolved Electrochemical Performance in a Segmented Planar SOFC
}

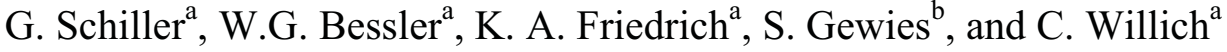 \\ ${ }^{a}$ Deutsches Zentrum für Luft- und Raumfahrt (DLR), Institut für Technische \\ Thermodynamik, Stuttgart, Germany \\ ${ }^{\mathrm{b}}$ Heidelberg University, Interdisciplinary Centre for Scientific Computing, Heidelberg, \\ Germany
}

Spatially inhomogeneous distributions of current density and temperature in solid oxide fuel cells (SOFC) can contribute significantly to accelerated electrode degradation, thermomechanical stresses, and reduced efficiency. A combined experimental and modeling study of the spatial distribution of the electrochemical performance was performed in order to determine local effects. A planar anode-supported SOFC single cell was locally characterized in a $4 \times 4$-segmented cell arrangement in dependence of gas composition and fuel utilization. A twodimensional elementary kinetic electrochemical model was used to quantitatively interpret experimental observations. The model was validated by comparison to experiments under a wide range of operating conditions. When the cell was operated at high fuel utilization, both measurements and simulations show a strong variation of the electrochemical performance along the flow path. The simulations predict a considerable gradient of gas-phase concentrations along the fuel channel and through the thickness of the porous anode, while the gradients are lower at the cathode side.

\section{Introduction}

In order to achieve optimum fuel cell performance and minimum degradation, a homogeneous electrochemical activity and temperature over the whole area of the electrodes is required. Inhomogeneous distributions of current density and temperature result in a reduced utilization of the reactants or the catalyst and, hence, in reduced efficiency. Furthermore, long-term stability of cell components are likely to be detrimentally affected by an inhomogeneous distribution of the electrical and thermal properties in the cell. For this reason, it is highly desirable to obtain detailed information about the spatial distribution of the electrical, chemical and thermal cell properties. For polymer electrolyte fuel cells (PEFC), different setups for the local measurement of particularly the current density distribution have been developed and are widely used (17). In contrast to this, only few experiments for a spatially resolved characterization of solid oxide fuel cells (SOFC) have been conducted so far, mainly because the high operating temperature represents a considerable challenge to the experimental setup. One of the first and most powerful setups for the local characterization of segmented SOFC cells has been developed at DLR Stuttgart (8-11) .

A more fundamental understanding of the complex behavior in cells in dependence of the local operating conditions can be achieved by combining experimental investigations 
with modeling studies. A two-dimensional electrochemical model representing the segmented cell along the flow path and through the thickness of the membrane-electrode assembly and interconnect has been established at the University of Heidelberg $(12,13)$. The model includes the description of gas-phase mass and heat transport in the interconnect channels and in the porous electrodes, the elementary kinetic heterogeneous and charge-transfer reactions in the electrodes, as well as mass and charge transfer in the membrane-electrode assembly. The model thus reflects the experimental setup in a highly detailed way and allows to quantitatively interpret the experimental observations.

Here we present results from the combined experimental and modeling study of the spatial distribution of the electrochemical performance in a planar SOFC. Goal of the study is the determination of local effects and identification of critical operating conditions during technically relevant SOFC operation.

\section{Experimental}

The measurement setup for segmented cells is shown schematically in Fig. 1. It allows for the integral and spatially resolved measurement of current density and voltage, the local and integral determination of impedance data, the local measurement of temperature and temperature distribution and the spatially resolved analysis of the fuel gas concentrations along the flow path. Square-shaped cells with an area of $100 \mathrm{~cm}^{2}$ are divided into 16 segments with an active area of $4.84 \mathrm{~cm}^{2}$ of each segment. The cells are integrated in a metallic cell housing and sealed with glass seal provided by Fraunhofer Institute of Ceramic Technologies and Sintered Materials (IKTS) in Dresden, Germany. The metallic housing is subdivided into 16 galvanically isolated segments with a total active area of $73.96 \mathrm{~cm}^{2}$. In order to determine the temperature at each segment, thermocouples are introduced in the metallic segments. Additionally, capillary tubes that correspond to the cathodic segments are integrated at the anode side at 16 measuring points to take samples of the anode gas to be analyzed by gas chromatography.

The setup is flexible with regard to the integration of different cell designs. Metalsupported cells (MSC), as they are developed and fabricated in house according to the DLR spray concept, as well as electrolyte-supported cells (ESC) and anode-supported cells (ASC) can be characterized. With MSC and ASC, only the cathode is segmented, whereas ESC are segmented on both the anode and the cathode side. The anodesupported cells used in this investigation contained a $540 \mu \mathrm{m}$ thick NiO/YSZ anode with a thin anode functional layer, a $\sim 5 \mu \mathrm{m}$ thick $8 \mathrm{YSZ}$ electrolyte, a $\sim 3 \mu \mathrm{m}$ thick YDC interlayer and a $\sim 45 \mu \mathrm{m}$ thick LSCF cathode. For the contact of the electrodes $\mathrm{Ni}$ and $\mathrm{Pt}$ meshes were used. More details on the measurement system are given in $(8,9)$.

\section{Modeling and Simulation}

A detailed two-dimensional multi-scale elementary kinetic electrochemical model was developed that represents one single channel of the experimental setup. The model layout is shown schematically in Fig. 2. The structural and operational model parameters are summarized in Table I. The modeling approach was presented in detail in (12) and is only 
summarized here. One-dimensional channel flow ( $x$ dimension) is described using the Navier-Stokes conservation equations (continuity, species, momentum). One-dimensional transport through the MEA ( $y$ dimension) is described by coupled mass transport (Fickian and Knudsen diffusion, Darcy flow) and charge transport (Ohm's law for the electrolyte). The results shown in this paper are calculated under the assumption of isothermal conditions.

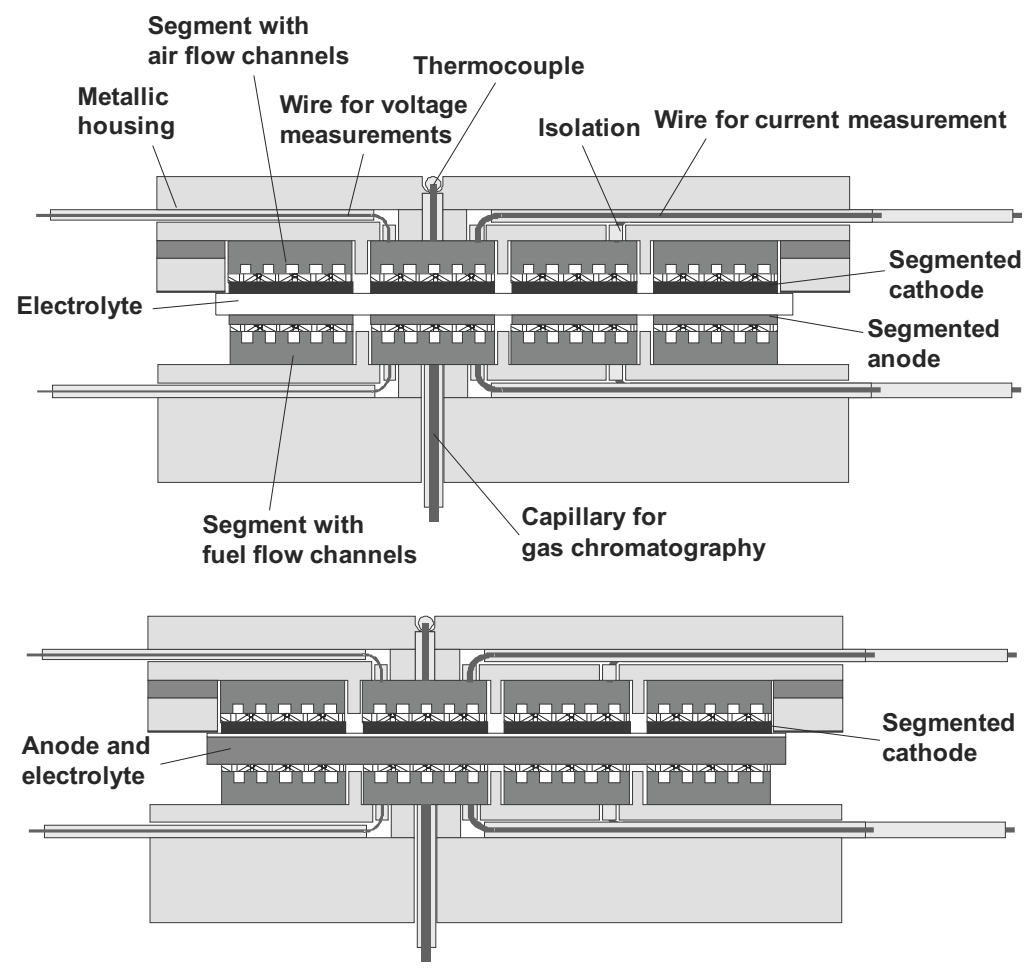

Fig. 1: Setup of measurement system for the characterization of planar segmented SOFCs: (a) Housing with anode and cathode segmentation used for electrolyte-supported cells; (b) Housing with cathode segmentation used for metal- and anode-supported cells.
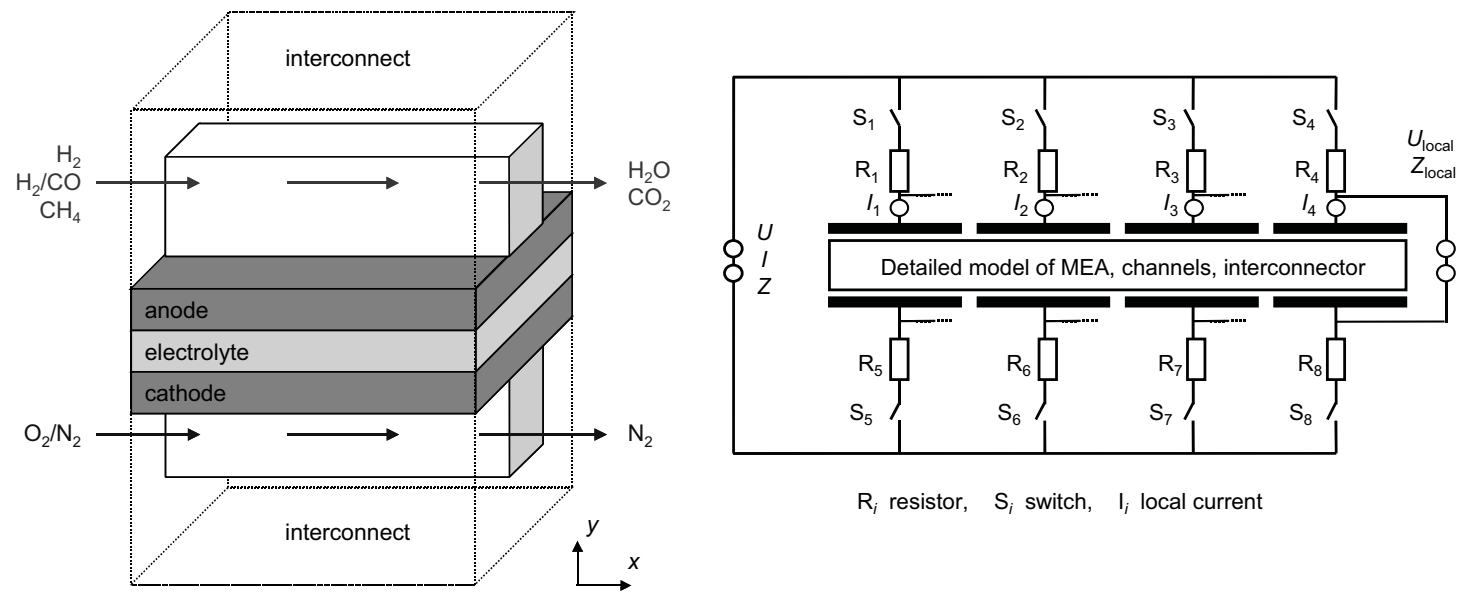

$\mathrm{R}_{i}$ resistor, $\mathrm{S}_{i}$ switch, $\mathrm{I}_{i}$ local current

Fig. 2: Model of the segmented SOFC. Left: two-dimensional representation of one single gas channel including MEA and interconnect. Right: representation of segmentation by an electrical circuit. 
Anode electrochemistry is described using elementary kinetics for surface reactions on $\mathrm{Ni}$ and YSZ, and for charge transfer (hydrogen spillover) (14). The reaction mechanism is given in Table 2. Cathode electrochemistry is limited to the porous electrode/solid electrolyte interface. It is described using an extended Butler-Volmer equation according to $i=i^{0} p_{\mathrm{O} 2}{ }^{a}[\exp (0.5 F \eta / R T)-\exp (-0.5 F \eta / R T)]$. Current-voltage relationships are modeled by directly solving for the electric-potential distribution in the electrodes and electrolytes without using the Nernst equation. The segmentation is represented by an electrical circuit model where an arbitrary number of segments can be used. All models are implemented in the in-house numerical simulation software DENIS.

Table I: Model parameters

\begin{tabular}{|c|c|c|}
\hline Model parameter & Value & Ref. \\
\hline \multicolumn{3}{|l|}{ Gas channel } \\
\hline Length & $8.8 \mathrm{~cm}$ & Setup \\
\hline Channel cross-sectional area & $4 \mathrm{~mm}^{2}$ & Setup \\
\hline Channel perimeter & $4 \mathrm{~mm}$ & Setup \\
\hline \multicolumn{3}{|l|}{ Segmented cell } \\
\hline Number of segments in one channel & 4 & Setup \\
\hline Segment area & $2.2 \mathrm{~cm} \times 2.2 \mathrm{~cm}$ & Setup \\
\hline \multicolumn{3}{|c|}{ Porous media (mesh anode (ma), cermet anode (an), porous cathode (ca), mesh cathode (mc)) } \\
\hline Layer thickness: ma, an, ca, mc & $\begin{array}{l}450 \mu \mathrm{m}, 540 \mu \mathrm{m}, 55 \mu \mathrm{m} \\
490 \mu \mathrm{m}\end{array}$ & Setup \\
\hline Porosity: ma, an, ca, mc & $0.74,0.32,0.40^{\mathrm{a}}, 0.82$ & Setup \\
\hline Pore size: $\mathrm{ma}$, an, ca, $\mathrm{mc}$ & $\begin{array}{l}100 \mu \mathrm{m}, 0.7 \mu \mathrm{m}, 0.5 \mu \mathrm{m}^{\mathrm{a}} \\
125 \mu \mathrm{m}\end{array}$ & Setup \\
\hline Particle size: ca, mc & $0.5 \mu \mathrm{m}^{\mathrm{a}}, 40 \mu \mathrm{m}$ & Setup \\
\hline Tortuosity: ma, an, ca, mc & $1.4^{\mathrm{a}}, 2.9^{\mathrm{b}}, 1.4^{\mathrm{a}}, 1.4^{\mathrm{a}}$ & \\
\hline \multicolumn{3}{|l|}{ Cermet anode parameter } \\
\hline Active three-phase boundary length & $4.5 \cdot 10^{12} \mathrm{~m} / \mathrm{m}^{3}$ & Micro- \\
\hline Effective width electrolyte & $0.43 \mu \mathrm{m}$ & structural \\
\hline Effective width electrode & $0.31 \mu \mathrm{m}$ & model (13) \\
\hline Structural factor electrolyte conductivity & 0.30 & \\
\hline \multicolumn{3}{|l|}{ Electrolyte layer } \\
\hline Effective thickness & $10 \mu \mathrm{m}$ & Setup \\
\hline $\begin{array}{l}\text { Conductivity bulk } 8 Y S Z \text { : preexponential factor, } \\
\text { activation energy }\end{array}$ & $\begin{array}{l}5.15 \cdot 10^{7} \mathrm{SK} / \mathrm{m} \\
84 \mathrm{~kJ} / \mathrm{mol}\end{array}$ & $(13)^{4}$ \\
\hline \multicolumn{3}{|l|}{ Additional resistances } \\
\hline Contact resistance & $0 \Omega \mathrm{cm}^{2 \mathrm{~b}}$ & Fit \\
\hline Resistance of wires & $1.4 \Omega \mathrm{cm}^{2 \mathrm{~b}}$ & Exp. \\
\hline \multicolumn{3}{|l|}{ Conditions } \\
\hline Temperature & $700-800{ }^{\circ} \mathrm{C}$ & Exp. \\
\hline Pressure & $1013 \mathrm{hPa}$ & Exp. \\
\hline Anode gas phases $\mathrm{H}_{2}, \mathrm{H}_{2} \mathrm{O}, \mathrm{N}_{2}$ & & Exp. \\
\hline Cathode gas phases $\mathrm{O}_{2}, \mathrm{~N}_{2}$ & & Exp. \\
\hline
\end{tabular}


Table II: Elementary kinetic reaction mechanism for the anode (14) and global kinetic reaction for the cathode. A single hydrogen spillover between Ni and YSZ surfaces is assumed as active charge-transfer reaction. A symmetry factor $\alpha=0.5$ is assumed. The surface site densities of $\mathrm{Ni}$ and $\mathrm{YSZ}$ are $3.2 \cdot 10^{-9}$ and $6.3 \cdot 10^{-10} \mathrm{~mol} / \mathrm{cm}^{2}$, respectively.

\begin{tabular}{|c|c|c|}
\hline Anode Reaction & Preexponential factor & Activation energy \\
\hline \multicolumn{3}{|l|}{ Charge transfer reaction (Fit): } \\
\hline $\begin{array}{l}\mathrm{H}_{\mathrm{Ni}}+\mathrm{OH}^{-} \mathrm{YsZ} \rightleftharpoons \square_{\mathrm{Ni}}+\mathrm{H}_{2} \mathrm{O} \text { YsZ } \\
\text { YSZ surface reactions: }\end{array}$ & $1.63 \cdot 10^{5} \mathrm{~mol} /(\mathrm{m} \mathrm{s})^{\mathrm{a}}$ & $235 \mathrm{~kJ} / \mathrm{mol}^{\mathrm{b}}$ \\
\hline $\mathrm{H}_{2} \mathrm{O}+\square_{\mathrm{YSZ}} \rightleftharpoons \mathrm{H}_{2} \mathrm{O}_{\mathrm{YSZ}}$ & $6.6 \cdot 10^{11} \mathrm{~mol} /\left(\mathrm{cm}^{3} \mathrm{~s}\right)$ & 0 \\
\hline $\mathrm{H}_{2} \mathrm{O}_{\mathrm{YSZ}}+\mathrm{O}^{2-} \mathrm{YSZ} \rightleftharpoons 2 \mathrm{OH}^{-}{ }_{\mathrm{YSZ}}$ & $1.6 \cdot 10^{22} \mathrm{~mol} /\left(\mathrm{cm}^{2} \mathrm{~s}\right)$ & $9.6 \mathrm{~kJ} / \mathrm{mol}$ \\
\hline $\begin{array}{l}\mathrm{O}_{\mathrm{OYSZ}}^{\mathrm{x}}+\square \mathrm{YSZ} \rightleftharpoons \mathrm{V}_{\mathrm{O}}{ }_{\mathrm{YSZ}}+\mathrm{O}^{2-}{ }_{\mathrm{YSZ}} \\
\text { Nickel surface reactions: }\end{array}$ & $1.6 \cdot 10^{22} \mathrm{~mol} /\left(\mathrm{cm}^{2} \mathrm{~s}\right)$ & $91 \mathrm{~kJ} / \mathrm{mol}$ \\
\hline $\mathrm{H}_{2}+2 \square \mathrm{Ni} \rightleftharpoons 2 \mathrm{H}_{\mathrm{Ni}}$ & $9.8 \cdot 10^{17} \mathrm{~mol} /\left(\mathrm{cm}^{5} \mathrm{~s}\right)$ & 0 \\
\hline $\mathrm{H}_{2} \mathrm{O}+\square{ }_{\mathrm{Ni}} \rightleftharpoons \mathrm{H}_{2} \mathrm{O}_{\mathrm{Ni}}$ & $1.4 \cdot 10^{10} \mathrm{~mol} /\left(\mathrm{cm}^{3} \mathrm{~s}\right)$ & 0 \\
\hline $\mathrm{H}_{\mathrm{Ni}}+\mathrm{O}_{\mathrm{Ni}} \rightleftharpoons \mathrm{OH}_{\mathrm{Ni}}+\square \mathrm{Ni}$ & $5.0 \cdot 10^{22} \mathrm{~mol} /\left(\mathrm{cm}^{2} \mathrm{~s}\right)$ & $98 \mathrm{~kJ} / \mathrm{mol}$ \\
\hline $\mathrm{H}_{2} \mathrm{O}_{\mathrm{Ni}}+\mathrm{O}_{\mathrm{Ni}} \rightleftharpoons 2 \mathrm{OH}_{\mathrm{Ni}}$ & $5.4 \cdot 10^{23} \mathrm{~mol} /\left(\mathrm{cm}^{2} \mathrm{~s}\right)$ & $209 \mathrm{~kJ} / \mathrm{mol}$ \\
\hline $\mathrm{H}_{\mathrm{Ni}}+\mathrm{OH}_{\mathrm{Ni}} \rightleftharpoons \mathrm{H}_{2} \mathrm{O}_{\mathrm{Ni}}+\square_{\mathrm{Ni}}$ & $3.0 \cdot 10^{20} \mathrm{~mol} /\left(\mathrm{cm}^{2} \mathrm{~s}\right)$ & $43 \mathrm{~kJ} / \mathrm{mol}$ \\
\hline Cathode Reaction & $\begin{array}{l}\text { Exchange current } \\
\text { density }\end{array}$ & $\begin{array}{l}\text { Exponent } a \text { for } \\
p_{\mathrm{O} 2}\end{array}$ \\
\hline $1 / 2 \mathrm{O}_{2}+\mathrm{V}_{\mathrm{O}}^{\bullet \bullet} \mathrm{e}^{-} \rightleftharpoons \mathrm{O}_{\mathrm{OYSZ}}^{\mathrm{x}}$ & $3.6 \cdot 10^{4} \mathrm{~A} / \mathrm{m}^{2 \mathrm{a}}$ & $0.47^{\mathrm{a}}$ \\
\hline
\end{tabular}

${ }^{a}$ Fitted to the present experiments.

${ }^{\mathrm{b}}$ Fitted to experiments with symmetrical SOFC anodes (13).

${ }^{c}$ Activation energy found with dense thin film electrodes (15).

\section{Results and Discussion}

\section{Calibration Measurements and Model Validation}

There are a number of model parameters associated with electrochemistry and transport in the MEA that are specific for the investigated cells and cannot be obtained from independent literature. Some parameters can be reliably estimated (e.g., porosity from SEM micrographs). Other parameters, however, can only be obtained by fitting to experimental data. Here, we use the electrochemical performance of anode and cathode (preexponential factors, resistance of contacts and wires) as well as porous anode tortuosity as free parameters. These parameters were fitted and the model validated under specifically designed operating conditions: Experimental polarization behavior was measured under low fuel utilization $(<15 \%$ by using fast gas inflow velocities) in order to circumvent spatial gradients along the channel. Gas-phase anode and cathode inlet concentrations as well as temperature were varied over a wide range of conditions (gas composition, gas dilution, temperature); these conditions were chosen in order to achieve sensitivity for the unknown parameters. Parameters were fitted using an isothermal onedimensional model of the MEA only. Fitting results are included in Tables 1 and 2. 
Simulated and experimental polarization curves for the validation conditions are shown in Fig. 3. There is overall good agreement between model and experiment over the complete range of operating conditions. However, a systematic deviation between model and experiment occurs during temperature variation. We believe that this is due to an onset of cell degradation, lowering the experimentally observed performance relative to the model predictions. Note that one single set of model parameters was used for all conditions. Degradation effects are not included in the model.

$\underline{\text { Measurement and Simulation under High Fuel Utilization }}$

The segmented cell was operated under an operating condition with high fuel utilization. The anode was fed with $33 \% \mathrm{H}_{2}, 1 \% \mathrm{H}_{2} \mathrm{O}$ and $66 \% \mathrm{~N}_{2}$ (simulated nitrogenrich reformate gas); the cathode was fed with air. Counter-flow operation was assumed, and temperature was set to $805^{\circ} \mathrm{C}$. The identical conditions were used for $2 \mathrm{D}$ simulations.
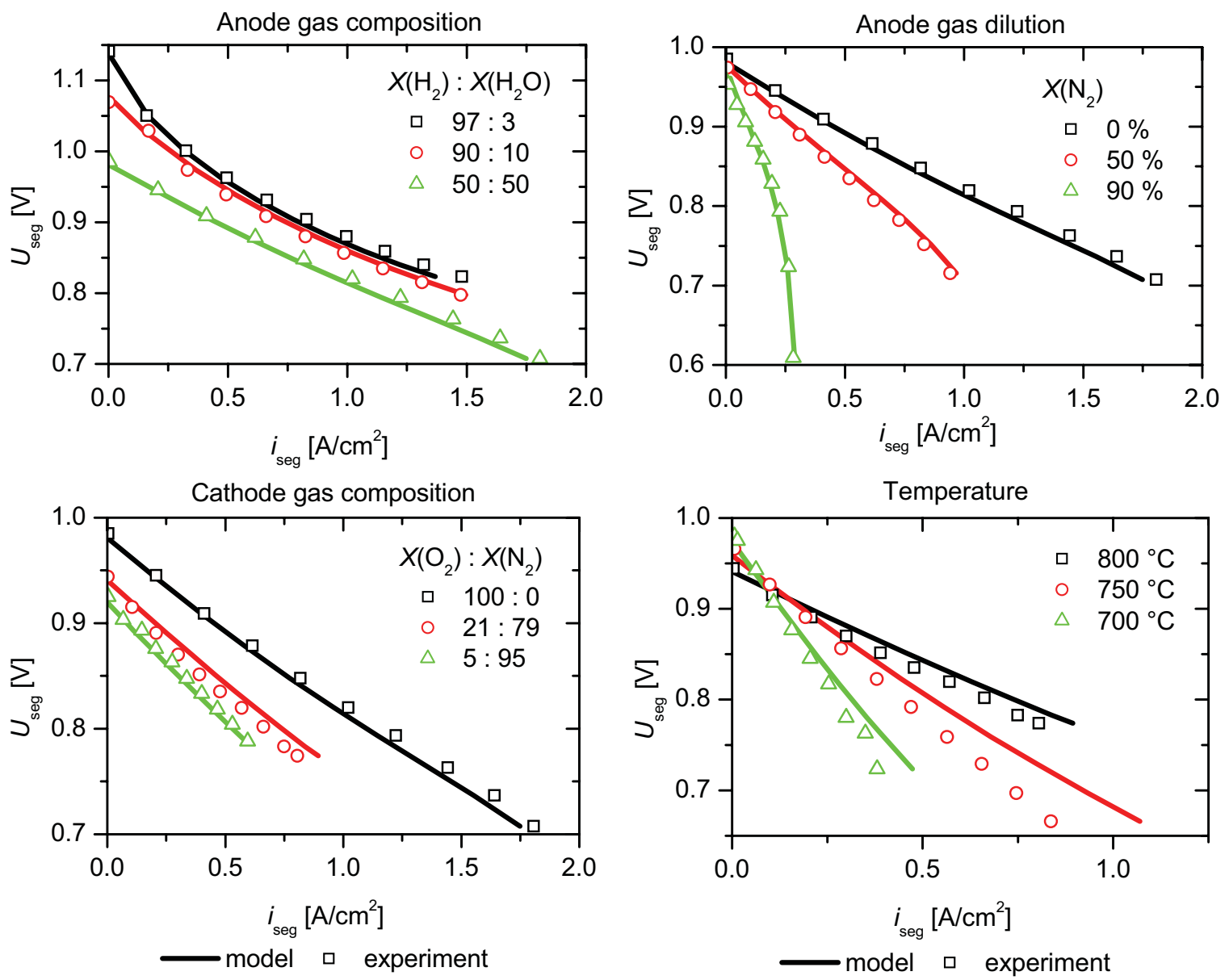

Fig. 3: Comparison of experimental data under validation conditions (low fuel utilization) and 1D model calculations. (a) Variation of anode gas composition with $X\left(\mathrm{~N}_{2}\right)=0$ at $800{ }^{\circ} \mathrm{C}$ with cathode $100 \% \mathrm{O}_{2}$; (b) Variation of anode gas dilution with $X\left(\mathrm{H}_{2}\right): X\left(\mathrm{H}_{2} \mathrm{O}\right)$ $=1: 1$ at $800{ }^{\circ} \mathrm{C}$ with cathode $100 \% \mathrm{O}_{2}$; (c) Variation of cathode gas composition at $800{ }^{\circ} \mathrm{C}$ with anode $X\left(\mathrm{H}_{2}\right): X\left(\mathrm{H}_{2} \mathrm{O}\right): X\left(\mathrm{~N}_{2}\right)=50: 50: 0$; (d) Variation of temperature with anode $X\left(\mathrm{H}_{2}\right): X\left(\mathrm{H}_{2} \mathrm{O}\right): X\left(\mathrm{~N}_{2}\right)=50: 50: 0$ and cathode air. 
Experimental and simulated global and local current-voltage characteristics for this condition are shown in Fig. 4. The global IV-curve (Fig. 4a) shows a typical shape with a parabolic behavior at low currents and a limiting current density of $\sim 0.8 \mathrm{~A} / \mathrm{cm}^{2}$. The local IV-curves are represented by plotting local segment voltage versus local segment current (Fig. 4b). The local behavior shows a considerable variation of the limiting current density for different cell segments. Both, global and local behavior show a good agreement between simulation and experiment.

Fig. 5 shows the spatially resolved distributions of gas-phase concentrations in the interconnector channels as well as in the porous electrodes and current collector meshes for the condition of maximum power density. There are considerable concentration gradients throughout the complete system. In particular, the relatively thick porous anode in this anode-supported cell is responsible for strong $\mathrm{H}_{2}$ depletion through the anode thickness. The upper panel of Fig. 5 also shows the local current density along the flow path. The step-like behavior over the four segments is due to the contribution of the resistance of current collector wires.

(a)

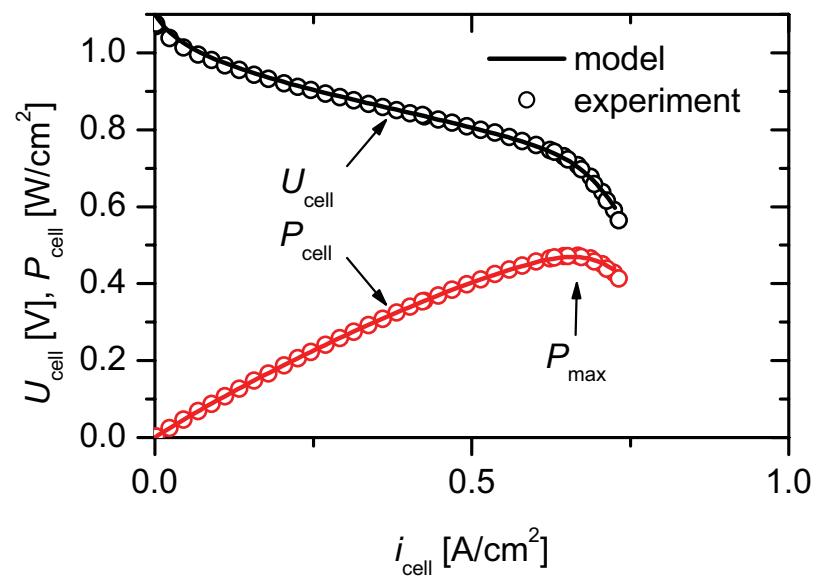

(b)

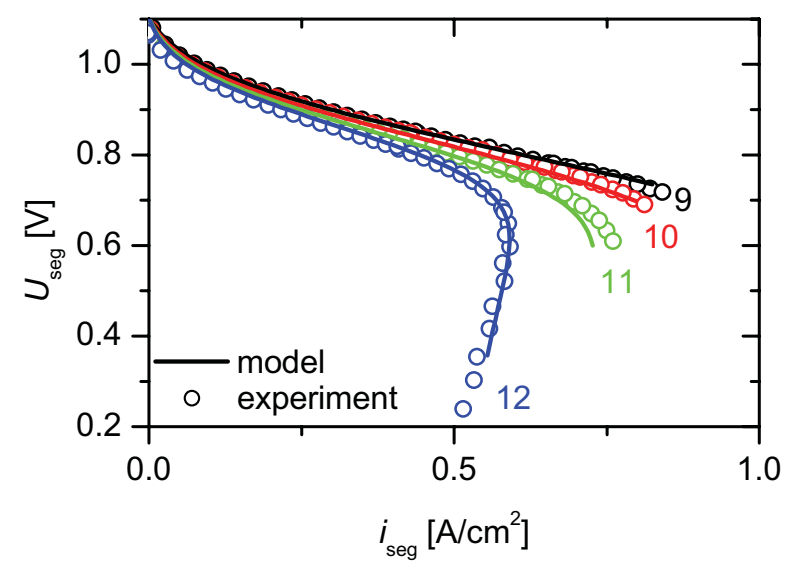

Fig. 4: Experimental and simulated polarization behavior for the segmented cell using the full 2D model under operating conditions with high fuel utilization (counter-flow operation; anode: $33 \% \mathrm{H}_{2}, 1 \% \mathrm{H}_{2} \mathrm{O}, 66 \% \mathrm{~N}_{2}$ in $\mathrm{H}_{2}, 1.1 \mathrm{~m} / \mathrm{s}$ inflow velocity; cathode: air, $5.2 \mathrm{~m} / \mathrm{s}$ inflow velocity; $T=805{ }^{\circ} \mathrm{C}$ ). (a) Global current-voltage curves. (b) Local segment voltage versus local segment current. The numbers indicate the segments, where segment 9 is the first in flow direction of the fuel gas. 


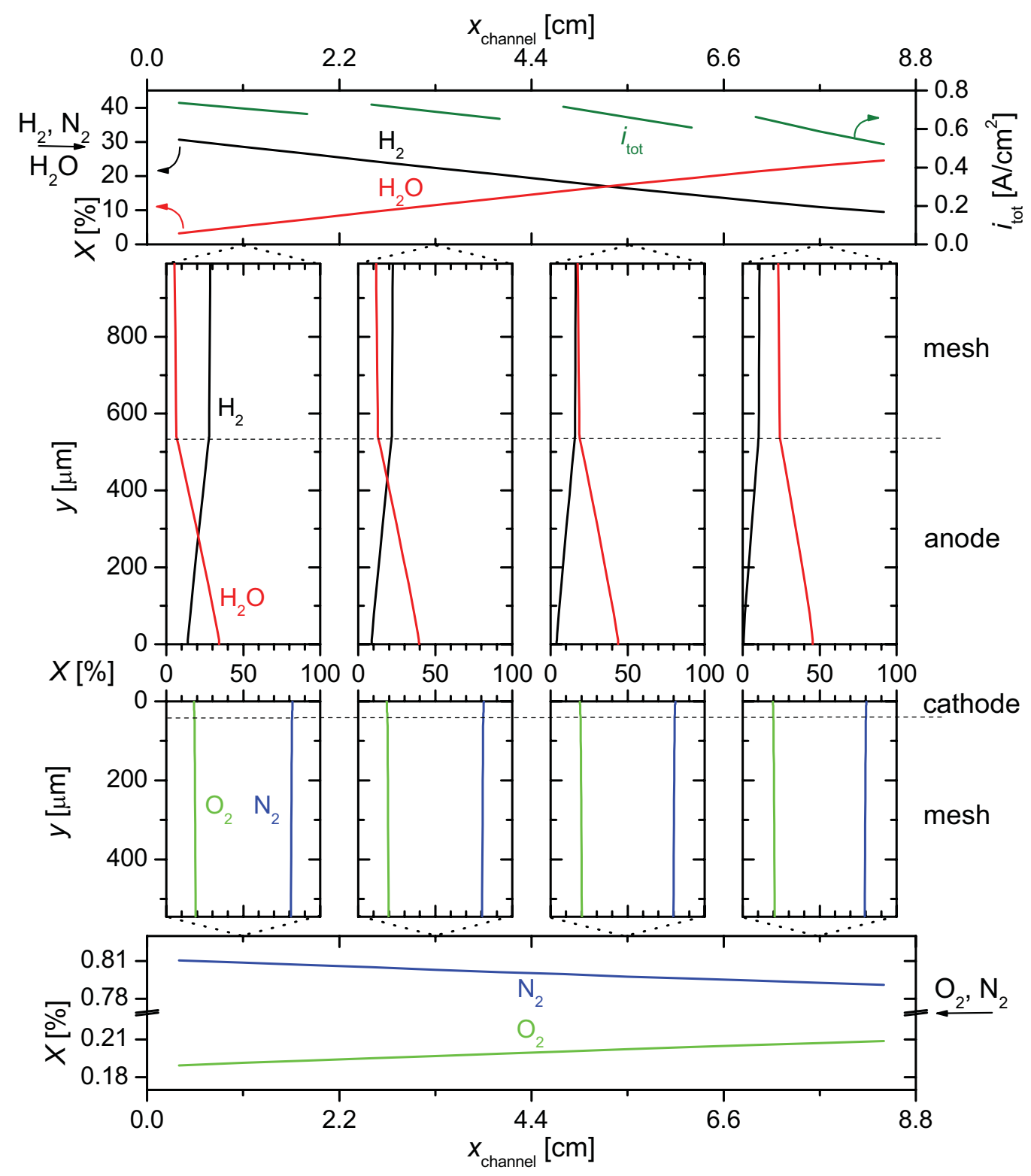

Fig. 5: Distribution of local current density and gas-phase concentrations within channel and porous electrodes on anode and cathode side for the point of maximum power density $P_{\max }$ (cf. Fig. 4).

\section{Conclusions}

A combined experimental and modeling study of the spatial distribution of the electrochemical performance in a planar SOFC was performed. Experimental data were obtained using a specifically designed segmented cell setup that allows the measurement of local current-voltage characteristics, gas composition and temperature. Simulations were performed using a two-dimensional elementary kinetic model that represents the experimental setup. 
Model parameters were identified by comparing simulations with validation experiments under low fuel utilization. A good agreement between simulation and experiment was observed. Experiments and simulations with high fuel utilization showed strong gradients of gas concentrations and current density along the flow path and throughout the thickness of the membrane-electrode assembly. The relatively thick porous anode and high fuel utilization causes particularly strong concentration variations at the anode, while the gradients are lower at the cathode side. We would therefore expect the anode to be more susceptible to spatially inhomogeneous degradation than the cathode.

\section{$\underline{\text { Acknowledgements }}$}

Funding was provided by the Umweltministerium Baden-Württemberg, Germany, through the programme "Herausforderung Brennstoffzelle".

\section{References}

1. M. Noponen, T. Tennola, M. Mikkola, T. Hottinen and P. Lund, J. Power Sources, 106, 304 (2002).

2. D. J. L. Brett, S. Atkins, N. P. Brandon, V. Vesovic, N. Vasileiadis and A. R. Kucernak, Electrochemsitry Communications, 3, 628 (2001).

3. N. Rajalakshmi, M. Raja and K. S. Dhathathreyan, J. Power Sources, 112, 331 (2002).

4. G. Bender, M. S. Wilson and T. A. Zawodzinski, J. Power Sources, 123, 163 (2003).

5. S. Schönbauer and H. Sander, in 3rd European PEFC Forum, p. B056, Lucerne, Switzerland (2005).

6. I. A. Schneider, S. A. Freunberger, D. Kramer, A. Wokaun and G. G. Scherer, J. Electrochem. Soc., 154, B383 (2007).

7. M. Schulze, E. Gülzow, S. Schönbauer, T. Knöri and R. Reissner, J. Power Sources, 173, 19 (2007).

8. P. Metzger, G. Schiller and A. O. Störmer, in 6th European Solid Oxide Fuel Cell Forum, p. 989, Lucerne, Switzerland (2004).

9. P. Metzger, K.-A. Friedrich, H. Müller-Steinhagen and G. Schiller, Solid State Ionics, 177, 2045 (2006).

10. P. Metzger, K. A. Friedrich, G. Schiller and H. Müller-Steinhagen, ECS Transactions, 7, 1841 (2007).

11. P. Metzger, K. A. Friedrich, G. Schiller and C. Willich, in 2nd European Fuel Cell Technology and Application Conference, Rome, Italy (2007).

12. W. G. Bessler, S. Gewies and M. Vogler, Electrochim. Acta, 53, 1782 (2007).

13. S. Gewies and W. G. Bessler, J. Electrochem. Soc., 155, B937 (2008).

14. M. Vogler, A. Bieberle-Hütter, L. J. Gauckler, J. Warnatz and W. G. Bessler, J. Electrochem. Soc., submitted (2008).

15. F. S. Baumann, J. Fleig, H.-U. Habermeier and J. Maier, Solid State Ionics, 177, 1071 (2006). 